\title{
Aldursgreiningar fylgdarlausra barna - hvers vegna og hvernig?
}
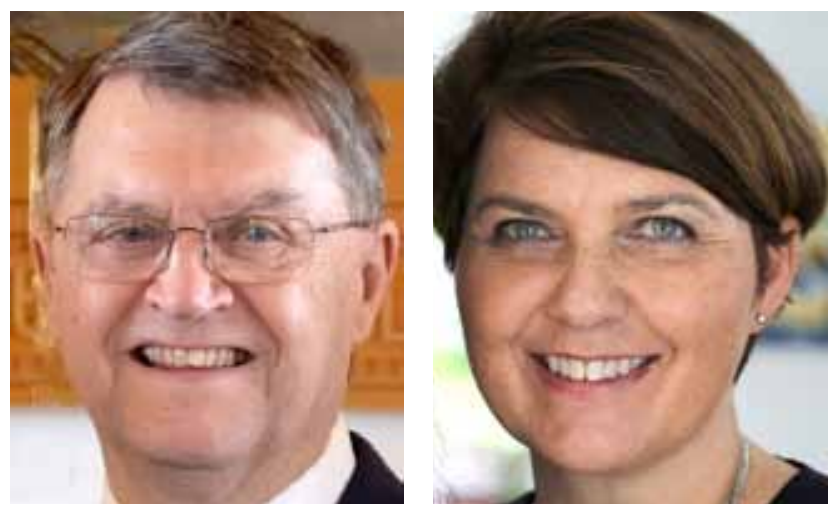

SVEND RICHTER, CAND. ODONT. DÓSENT EMERITUS, TANNL/EKNADEILD HÁSKÓLA ÍSLANDS SIGRÍĐUR RÓSA VÍĐISDÓTTIR, CAND. ODONT. LEKTOR, TANNL/EKNADEILD HÁSKÓLA ÍSLANDS

NETFÖNG: svend@hi.is, srv2@hi.is TANNLÆKNABLAĐIĐ 2020; 38: 22-34

doi: 10.33112/tann.38.1.3

\section{ÁGRIP}

UNICEF telur að fæðingar nærri priðjungi (35\%) barna undir fimm ára aldri hafa aldrei verið skráðar. Fæstar eru skráningarnar í Afríku sunnan Sahara (44\%) og Suður Asíu (39\%), paðan sem flest fylgdarlaus börn koma og leita verndar í Evrópu. Mörg peirra vita ekki um fæðingardag sinn og ferðast án viðeigandi persónuskilríkja. Vegna reglna um réttindi og skyldur einstaklinga sem sækja um alpjóðlega vernd, er lagalegur munur á hvort barn eða fullorðinn á í hlut. Pví er yfirvöldum innflytjendamála mikilvægt að ganga úr skugga um hvort einstaklingur sé yngri eða eldri en 18 ára.

Flest lönd Evrópu framkvæma réttarlæknisfræðilega aldursgreiningu ef ekki er hægt með hæfilegri vissu á grundvelli annarra tiltækra trúverðugra upplýsinga að meta aldur. Í aðeins tveimur löndum Evrópusambandsins, Bretlandi og Slóveníu, er aldursgreining byggð á viðtölum, án neinnar réttarlæknisfræðilegrar greiningar af neinu tagi. Langflest lönd Evrópu byggja aldursgreiningar á sampættingu tanna- og beinproska. Öll Norðurlöndin nota proska tanna til aldurgreininga og öll nota beinproska. Pau lönd sem nota proska beina til aldursgreininga nota öll hönd og úlnlið, nema Svípjóð sem notar hné. Í Danmörku, eitt Norðurlanda, er notað mat á kynproska við aldursákvörðun. Nokkur ágreiningur hefur verið um aldursgreiningar í Noregi, Svípjóð og Íslandi. Nokkrar sérfræðigreinar hafa verið kallaðar til að sjá um breytingar til bóta í Noregi og Svípjóð: tannlækningar, barnalækningar, röntgenfræði, en einnig hefur verið gerð tölfræðilíkön og myndgreining. Peir sem helst hafa haft sig frammi um hvernig best sé staðið að aldursgreiningu hér á landi hafa ekki komið frá pessum sérfræðigreinum heldur alls óskyldum. Gerður var samningur milli Útlendingastofnunar og Háskóla Íslands sem ekki var endurnýjaður eftir eitt ár par sem Hí taldi að ÚTL hefði ekki uppfyllt samninginn.

Lykilorð: Aldursgreining, fylgdarlaus börn, Evrópa, Ísland.

\section{Inngangur}

\section{Fæðingarvottorð}

Fylgdarlaus börn sem sækja um alpjóðlega vernd á Íslandi, á Norðurlöndum eða annars staðar í Evrópu eru oft ómeðvituð um nákvæman fæðingardag, ferðast án ábyggilegra persónuskilríkja eða koma með skýrteini af óvissum uppruna (1). Varðandi réttindi og skyldur einstaklinga sem sækja um alpjóðlega vernd er verulegur lagalegur munur gerður á ólögráða börnum og fullorðnum. Fyrir yfirvöld og sérstaklega útlendingastofnanir, er mikilvægt að ákvarða hvort einstaklingurinn sé eldri eða yngri en 18 ára (2). Læknisfræðilegt aldursmat er framkvæmt í nánast öllum ríkjum Evrópu ef ekki reynist unnt með skynsamlega öruggum hætti að afla upplýsinga um aldur pess sem segist vera fylgdalaust barn (e. unaccompanied minor) (3). Fyrir íslensk yfirvöld og önnur lönd sem búa við svipaðan 
lagaramma er mikilvægt að gengið sé úr skugga um að greint sé á milli barna og fullorðinna til að hægt sé með sem nákvæmlegustum hætti að tryggja börnum rétt sinn sem peim er ætlaður samkvæmt skuldbindingum sem Ísland og önnur ríki hafa undirgengist og koma í veg fyrir að fullorðnir taki sér pann rétt sem ætlaður er börnum.

Fæðingar nærri priðjungi barna undir fimm ára aldri hafa aldrei verið skráðar (4). Barnahjálp Sameinuðu pjóðanna, UNICEF, telur að nafn og pjóðerni sé réttur hvers barns, sem er staðfest í Barnasáttmálanum og öðrum alpjóðasamningum. Engu að síður hefur fæðing nærri 230 milljóna barna yngri en fimm ára aldrei verið skráð. Pessi skortur á formlegri viðurkenningu ríkja merkir að barn getur ekki fengið fæðingarvottorð. Fyrir vikið getur einstaklingur í peirri stöðu verið synjað um heilbrigðispjónustu eða menntun. Ef einstaklingar eru sakaðir um lögbrot geta óskráð börn verið sótt til saka sem fullorðnir og erfitt að sækja réttindi sem tryggð eru börnum í alpjóðasáttmálum. Á fullorðinsárum getur verið krafist persónuskilríkja sem byggja á fæðingavottorði til að fá vegabréf, félagslega aðstoð, ganga í hjónaband, fá réttindi til erfða, kosningarétt og margt fleira sem pykja sjálfsögð réttindi. Að skrá börn við fæðingu er fyrsta skrefið í að tryggja peim viðurkenningu fyrir lögum og verndun réttinda. Pað er pví ljóst að pessi priðjungur barna undir 5 ára aldri sem fengu ekki lögformleg fæðingarskýrteini urðu að verða sér út um pau á annan hátt, oftast á ólöglegum markaði götunnar (5).

Á Mynd 1 má sjá hvaða lönd standa verst að vígi meðútgáfu réttra fæðingavottorða, en pað eru Afríkulöndin sunnan Sahara og Suður-Asía. Pað er einmitt frá pessum löndum sem flestir flóttamenn koma til Evrópu svo og til Norðurlanda. Fylgdarlaus ungmenni án ábyggilegra persónuskilríkja eru verkefni sérfræðinga til að tryggja peim rétt sinn. petta er gert með peim aðferðum sem ábyggilegastar pykja hverju sinni og ríki vilja til kosta (4).

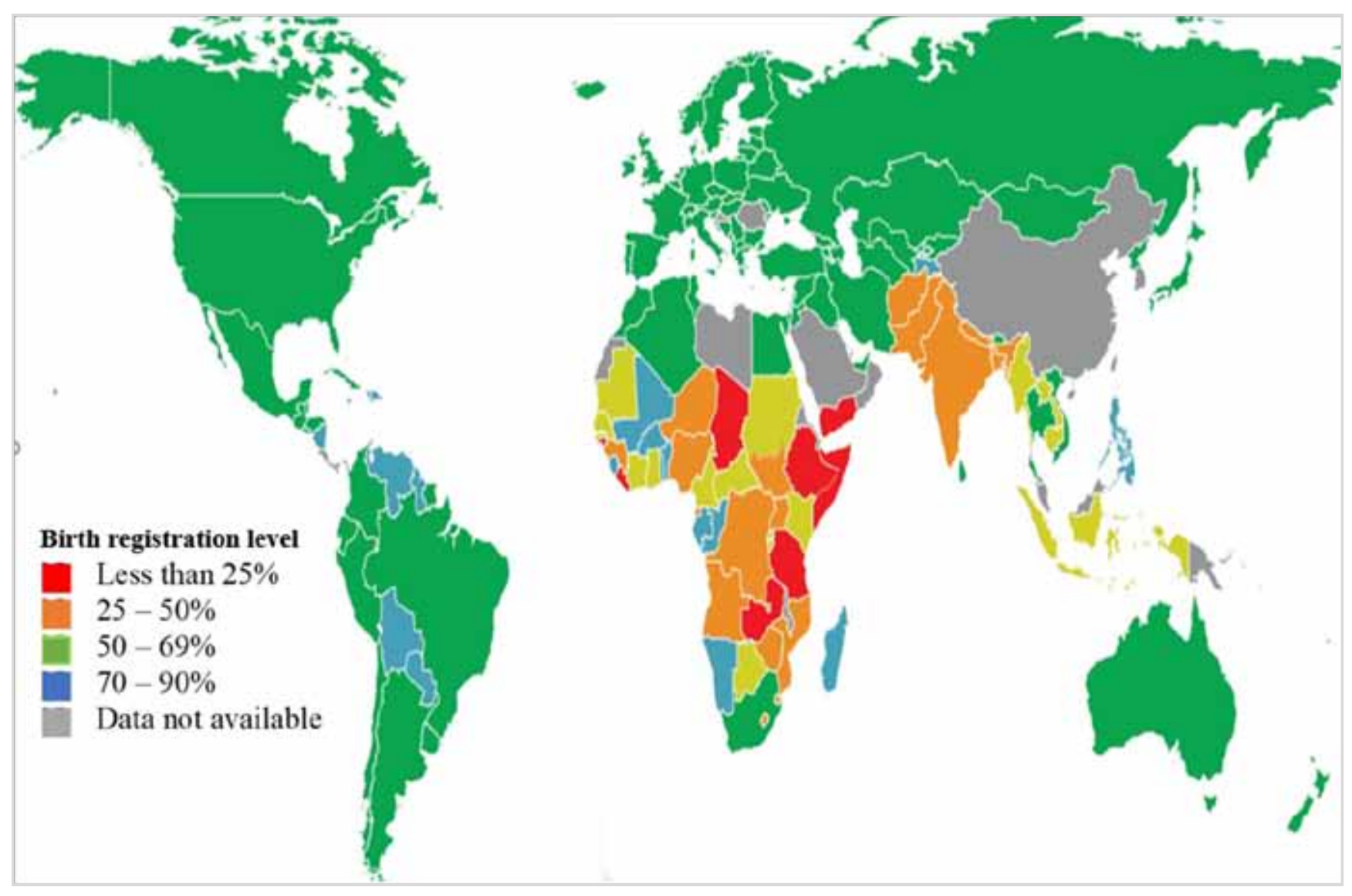

Mynd 1. Hlutfall barna innan 5 ára með fæðingavottorð eftir löndum. Hlutfallslega eru fæst fæðingavottorð útgefin í Afríkulöndum sunnan Sahara og í Suður-Asíu. Heimild: Every Child's Birth Right: Inequities and trends in birth registration. UNICEF, New York, 2013.

Figure 1. Percentage of children under age five whose births are registered by country. The lowest birth registration levels are found in sub-Saharan Africa but also in South Asia. Source: Every Child's Birth Right: Inequities and trends in birth registration. UNICEF, New York, 2013. 


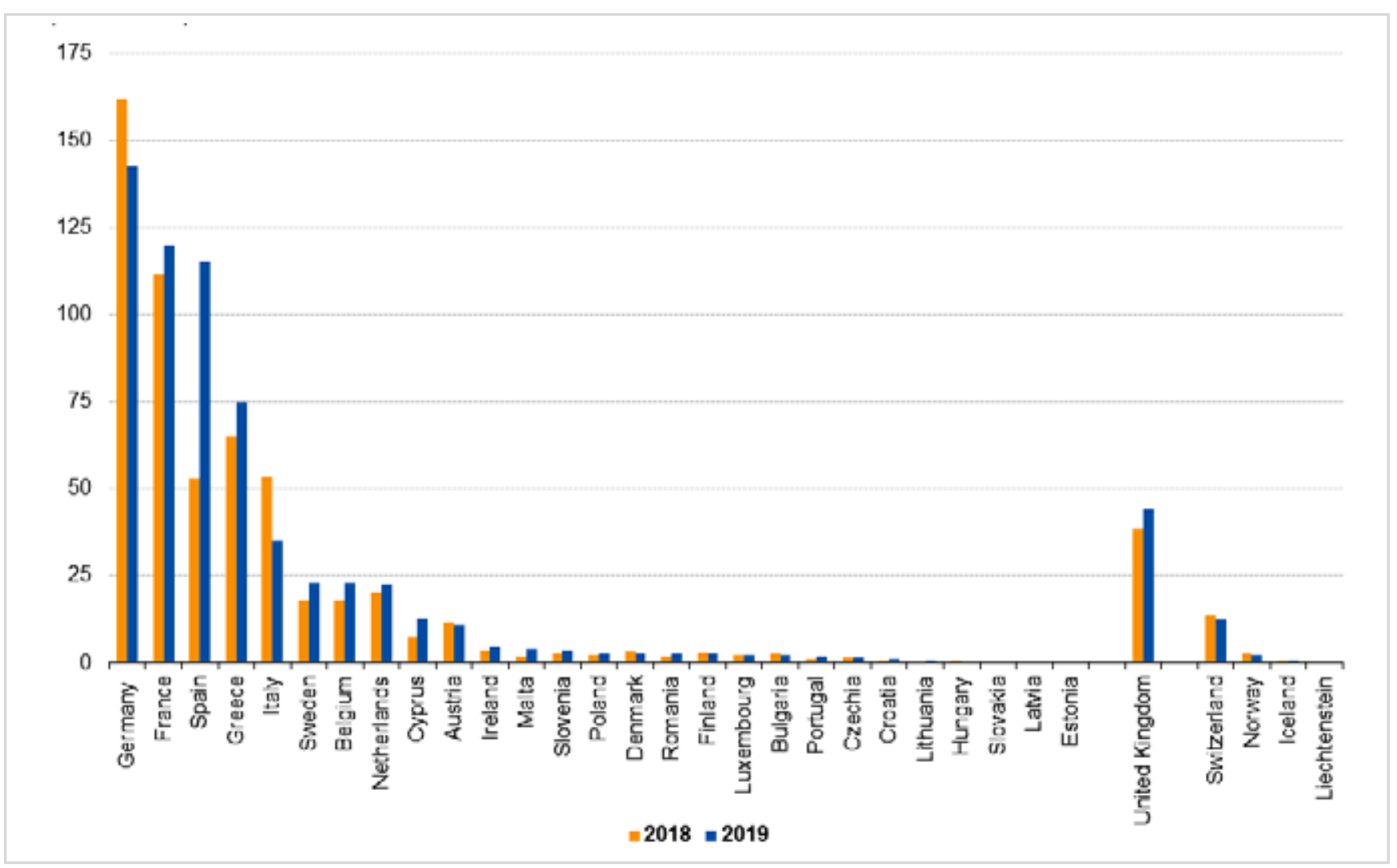

Mynd 2. Fjöldi einstaklinga sem sækja um alpjóðlega vernd til 27 ESB aðildarríkja, Bretlands og EFTA ríkja, 2018 og 2019 (púsundir af fyrstu umsókn). Heimild: Eurostat (tilvísun: migr_asyappctza).

Figure 2. Number of (non EU) asylum seekers in the EU-27 Member States, the United Kingdom and EFTA countries, 2018 and 2019 (thousands of first time applicants).Source: Eurostat (online code: migr asyappctza).

\section{Hvað er aldursgreining?}

Raunaldur (chronological age) er mældur íárum, mánuðum og dögum frá pví augnabliki sem einstaklingur fæðist. Enginn getur með nokkru móti greint raunaldur með neinum pekktum aðferðum. Lögformlegt opinbert fæðingarvottorðútgefið við fæðingu er eini möguleikinn til að segja til um raunaldur. Með aldursgreiningu er leitast við að áætla raunaldur út frá gefnum forsendum. Pegar réttarlæknisfræðilegum aðferðum er beitt er talað um líffræðilegan aldur (e. biological age) sem er áætlaður aldur sem byggður er á líffræðilegum/ læknisfræðilegum gögnum. par sem gera verður greinamun á raunaldri og líffræðilegum aldri sem er áætlaður er slíkt nefnt á ensku age estimation og age assessment (6). Peir sem til pekkja nota pví ekki hugtökin aldursákvörðun, age determination. Notaðar eru gagnreyndar, vísindalegar aðferðir sem byggja á rannsóknum sem viðurkenndar eru af vísindasamfélaginu par sem fyrir liggja staðalfrávik og öryggismörk.

Gagnrýnendur réttarlæknisfræðilegrar aldursgreiningar, m.a. hér á landi, benda á nauðsyn sálfræðiviðtala pegar mat er lagt á aldur. Aldur sem byggist á sálfræðiviðtölum uppfyllir ekki slík skilyrði. Norska heilbrigðisráðuneytið (Folkehelseinstituttet) lét sérfræðinga rannsaka kerfisbundið birtar greinar sem fjölluðu um aldursgreiningu ungmenna með sálfræðigreiningu á proska. Leitað var í gagnagrunnunum Cochrane Central Register of Controlled Trials (CENTRAL), MEDLINE, Embase, Google Scholar, PROSPERO and Epistemonikos í maí 2018. Af 3.325 titlum og ágripum virtust í fyrstu 7 greinar uppfylla skilyrði rannsakenda (inclusion criteria) en „engin peirra reyndist við nánari skoðun uppfylla skilyrði okkar.. Niðurstaða rannsóknarinnar var að „,engin fyrirliggjandi rannsóknargögn liggja fyrir um gagnsemi eða gildi sálfræðilegra proskaprófa til aldursgreininga" (7).

\section{Munur á tanna- og beinproska eftir kynpáttum}

Munur er á beinproska eftir kynpáttum, en næringar- og pjóðhagsleg staða (e. socioeconomic status) hefur mest áhrif. Reikna má með að peir sem búa við pjóðhagsleg krappari kjör búi við seinni beinproska en peir sem búa við betri kjör (8-10). Aðrar rannsóknir benda til að munur milli beinaldurs og 
raunaldurs sé lítill. Sýnt hefur verið fram á að með pví að nota saman greiningu á hönd og úlnlið samhliða annarri aðferð til aldursgreininga pá eykst nákvæmni aldursgreiningarinnar (11-13).

proski tanna er að mestu leyti erfðastýrður og áhrif ytri pátta eru í lágmarki $(14,15)$. Beitt er mismunandi aðferðum við mat á proska tanna til að auka nákvæmni. Lögð er áhersla á hagsmuni pess sem greindur er og óvissa túlkaður honum í hag og ef möguleiki er á að hann sé yngri en 18 ára, er hann aldursgreindur sem barn. Proski tanna er mjög stöðugt ferli í mannslíkamanum. Einstaka sinnum koma fram frávikí proska sem stafa að mestu leyti vegna erfðatruflana, áunninna eða sjálfvakinna vandamála. pekktar eru erfðatruflanir eins og osteopetrosis $(16)$ og ectodermal dysplasia $(17,18)$. Pótt slíkar truflanir hafi áhrif á myndun tanna, hafa pær ekki áhrif á hraða proska peirra. Meðferð nokkurra tegunda krabbameina hjá börnum með geislum og lyfjameðferð hafa sýnt proskatruflanir á tönnum. Pekkt er truflun á tannproska í kjölfar ígræðslu blóðmyndandi stofnfruma hjá ungum börnum (19). Allt eru petta mjög sjaldgæf tilfelli en parf að hafa í huga.

Tannmyndun og komutími tanna hinna ýmsu pjóða hefur verið rannsökuð mjög mikið undanfarin ár (20-26). Meðal ýmissa pjóða sýndi aðferð Demirjian (20) hærri aldur en raunaldur $(27,28)$. Par gekk aðferð Willems og fél. betur $(27$, 29, 30). Sýnt hefur fram á að næringarástand á uppvaxtarárum hefur ekki áhrif á tannproska (9). Enn fremur liggja fyrir vandaðar rannsóknir á heimsvísu á proskaferli endajaxla meðal hinna ýmsu kynpátta og pjóðabrota (13, 21, 31-35). Sá proskamunur tanna sem kann að vera milli kynpáttar er ekki meiri en rúmast innan öryggismarka hvers kynpáttar $(1,36,37)$. Petta pýðir að mat á endajöxlum sem enn eru að myndast seint á tvítugsaldrinum mun enn halda áfram sem hingað til að vera besti fáanlegi mælikvarðinn til að meta aldurbilið 18-20 ára $(38,39)$.

\section{AGFAD}

prátt fyrir að aldursgreining sem notuð er pegar borin eru kennsl á látna menn eigi sér langa hefð í réttarvísindum, hefur aldursgreining lifandi einstaklinga orðið að tiltölulega nýju sviði innan réttarrannsókna sem verður sífellt mikilvægari. Alpjóðlegur pverfaglegur rannsóknarhópur vísindamanna um réttarfarslegar aldursgreiningar, Group on Forensic Age Diagnostics (AGFAD) hefur starfað á priðja áratug. Pessi hópur heldur árlega fundi par sem rannsóknaniðurstöður fremstu sérfræðinga eru kynntar. Íslenskir sérfræðingar á pessu sviði hafa sótt pessa fundi um árabil. AGFAD hefur lagt fram tillögur um aðferðafræði aldursgreininga lifandi einstaklinga m.a. í págu rannsókna sakamála, einstaklinga sem sækja um alpjóðlega vernd og mansalsmála, en einnig til greiningar aldurs og kyns látinna. Í peirri vinnu settu höfundar fram ábendingar um aldursgreiningu fyrir tiltekna hópa, skilgreindu lágmarkskröfur til viðmiðunarrannsókna og tilgreindu pörfina fyrir frekari rannsóknir. Að auki er fjallað um siðferðilega og réttarlæknisfræðilega (e. medico-legal) pætti og mál sem tengjast gæðatryggingu (40).

Geislun við röntgenmyndatöku við aldursgreiningar Geislun er mæld í Sievert (Sv). Til að kanna hvort skaði sé af geislaálagi sem notað er við röntgenmyndatöku við aldursgreiningu, er hægt að bera pað saman við náttúrulega bakgrunnsgeislun (41). Að meðaltali er árleg bakgrunnsgeislun á menn 2000-2500 $\mu$ Sv (5 microSivert/dag). Petta pýðir að geislaskammtar sem notaðir eru við breiðmyndatöku, OPG,

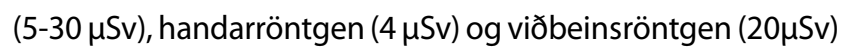
eru til samans álíka og geislaskammtar sem viðkomandi fær úr umhverfi sínu á 10 dögum. Sett í samhengi við ferðalag fylgdarlauss barns pá er geimgeislun (e. cosmic radiation) Cameroon-Belgiu $26.65 \mu$ Sv eða álíka mikið geislaálag og af pessum premur aðferðum til aldursgreininga. Talið er að af meðaltali verði flugáhafnir fyrir 1.5 til $1.7 \mathrm{mSv}$ (milliSivert), 1.500 - $1.700 \mu \mathrm{Sv}$ geimgeislunar árlega (41).

Eðli geislunar á menn er að hún safnast upp í líkamanum (e. cumulative). Einstaklingar sem sækja um alpjóðlega vernd og komið hafa til aldursgreininga hér á landi hafa fæstir komist undir læknishendur eða fengið geislun vegna læknisfræðilegra greininga eða meðferðar.

\section{Aldursgreiningar í Evrópu}

prátt fyrir ábendingar AGFAD hópsins eru engir sameiginlegir staðlar, ábendingar eða fyrirmæli um aðferðir við réttarfarslegar (medico-legal) aldursgreiningu á heimsvísu (42) eða innan Evrópu eða Evrópusambandsins (2, 3, 42). Einstök ríki ráða hvaða aðferðum er beitt og eru pær sniðnar að lagaumhverfi hvers lands. Árið 2018 var eftirfarandi aðferðum við réttarfarslegar aldurgreiningar beitt i 30 Evrópulöndum, myndgreining af hönd- og úlnlið í 23 löndum, tönnum 20, viðbeini 12, tanna- og munnskoðun 17 , greining á kynproska 7 og mat á líkamsproska í 11 löndum. Í sumum löndum eru notaðar aðrar aðferðir en læknisfræðilegar og má par nefna að framlögð skilríki er notað i 27 löndum og viðtöl í 17 löndum. Einnig eru 11 lönd sem notuðu mat félagsfræðinga (e. social services assessment) og 6 lönd notuðu sálfræðilegt mat til aldursgreininga (3).

$X$ : For victims of trafficking in human beings or vulnerable persons $\mathrm{XX}$ : Visual assessment 


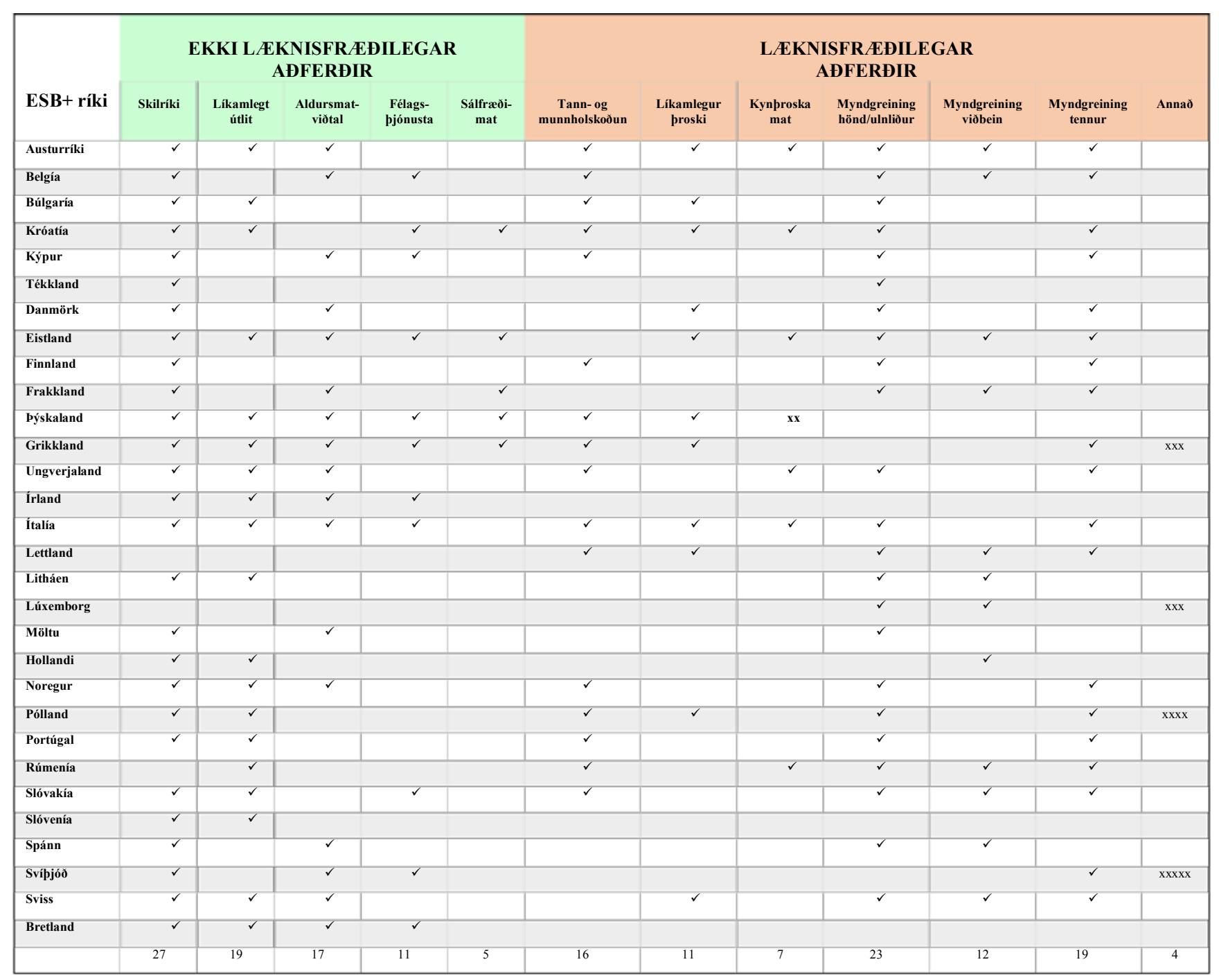

XXX: Pelvic bone X-ray

$X X X X$ : Fourth rib (PT)

$X X X X X: M R I$ of knee

(68): The initial estimation of age is only a guide, it is determined by this estimation that a person is a minor. If he/she claims to be a minor and is suspected to be adult, a medical examination is always undertaken. So the principle of benefit of the doubt is used in this initial estimation.

(69): In SK there are only some consultations with social workers.

X: Fyrir fórnarlömb mansals eða viðkvæma einstaklinga

$X X:$ Sjónrænt mat

$X X X:$ Röntgenmynd af mjaðmagrindarbeini

$X X X X$ : Fjórða rifbein (PT)

XXXXX: segulómun á hné

(68): Upphafsmat aldurs er aðeins leiðarvísir, pað ræðst af pessu mati að einstaklingur sé ólögráða. Ef hann / hún segist vera ólögráða og grunur leikur á að hann sé fullorðinn er alltaf notuð læknisskoðun. pannig að meginreglan um ávinning af vafa notuð í pessu upphaflega mati.

(69): I SK eru frekar lítil samráð við félagsráðgjafa.

Mynd 3. Yfirlit yfir aðferðir og öryggisráðstafanir við aldursgreiningu eftir löndum í Evrópu. Heimild: Annex 4. Overview of the methods and procedural safegards in use. EASO Practical Guide on age assessment, second ed. EASO, European Asylum Support Office 2018.

Figure 3. Overview of the methods and procedural safeguards in use in the age assessment process. Source: Annex 4. Overview of the methods and procedural safegards in use. EASO Practical Guide on age assessment, second ed. EASO, European Asylum Support Office 2018.

\section{Aldursgreiningar á Norðurlöndum}

Finnland 
Einstaklingur sem sækir um alpjóðlega vernd er tekinn í skoðun hjá réttartannlækni á Réttarmeinadeild Háskólans í Helsinki. Utan Helsinki getur skoðunin farið fram á staðarsjúkrahúsum eða heilsugæslustöðvum sveitarfélaga áður en myndgreining fer fram. Skráð er kyn, kynpáttur, uppgefinn aldur og næringar- og heilsufarsupplýsingar tengdar uppvexti. Upplýsingar um systkini og aldur peirra eru skráðar. pyngd og hæð eru mæld.

Hin réttarlæknisfræðilega aldursgreining sem byggist á röntgenrannsókn felur í sér breiðmyndatöku (orthopantomogram) af tönnum, og kjálkum og röntgenmynd af vinstri hönd og úlnlið, en einnig eru oft teknar smámyndir (intraoral periapicals) einkum pegar endajaxlar eru að ljúka eða hafa lokið proskaferli sínum og upplýsingar stangast á við uppgefinn aldur.

Röntgengreining af kjálkum og tönnum er rannsökuð óháð af tveimur réttartannlæknum. Tilvísanir í proska tanna eru valdar eftir viðtalið og röntgenmyndatöku. Kynpáttur einstaklingins getur haft áhrif á val greiningaraðferða við mat á tannproska.

1. Ef tennur fyrir framan endajaxla hafa ekki hafa lokið proskaferli sínu eru notaðar prjár af eftirtöldum fjórum aðferðum: Nyström og fél. (43), Kataja og fél. (44), Chaillet og fél.(45) og Willems og fél. (29). Pessar aðferðir byggjast á proskastigum Demirjian (20).

2. Pegar allar aðrar tennur en endajaxlar hafa náð fullum proska eru proskastig endajaxla algengasta aðferð til aldursgreiningar. Notaðar eru greiningaraðferðir Mincer, pekkt sem A.B.F.O. aðferð, sem grundvölluð er á bandarísku og afróbandarísku rannsóknarpýði (21), Orhan og fél. sem byggir á tyrknesku rannsóknarpýði (22) og töflur AIQahtani (23). Pessar prjár aðferðir eru notaðar svo fremi að endajaxlar séu til staðar. Ef ekki, er hægt að áætla aldur fullorðinna með aðferð Kvaal og fél. sem byggir á minnkun tannkviku vegna síðbúinnar tannbeinsmyndunar (secundary dentin formation) sem greind er af smáröntgenmyndum (e. intraoral) (25).

Til að finna áætlaðan aldur af beinproska er röntgenmynd af vinstri hönd og úlnlið borin saman við atlas Greulich and Pyle (46). Ólíkt við proska tanna getur purft að taka til greina kynpátt, vannæringu og alvarlega sjúkdóma sem og breytileika einstaklinga, sem geta haft áhrif á proska beina og taka verður tillit til við mat á beinaldri. Vannæring og sjúkdómar geta annað hvort seinkað eða sjaldnar flýtt fyrir beinaldri annað hvort beint eða með peirri læknishjálp sem beitt er gegn peim. Til dæmis hraða vaxtarhormón beinproska, en ýmsir sterar draga úr proska beina (47-49).
Pegar handa- og úlnliðsbein eru fullproskuð, er proski allra tanna framan við endajaxla lokið (Demirjian stig $\mathrm{H}$ ) og myndun róta endajaxla næstum lokið (stigi G) (20). pá myndi niðurstaða aldursgreiningar vera sú, að líkur á að einstaklingur væri 18 ára í bandarísku karlapýði væri 56\% (21). Miðgildi og staðalfrávik fylgja með $(21,22)$. Ef uppgefinn aldur er t.d. 16 ár stæði í niðurstöðu aldursgreiningar að aldur sé innan mögulegra marka og sá sem er til greiningar sé barn. Pegar endajaxlar eru fullmyndaðir (stig H) eru líkurnar samkvæmt Mincer 90,1\% samkvæmt tilvísun í sama pýði (21) og pví yfirgnæfandi líkur á að viðkomandi sé fullorðinn (21-23)

pegar QMUL-atlas er notaður er yfirleitt gefið upp aldursbil. Réttartannlæknar sjá um röntgengreiningu handar og úlnliðs, en pað er liður í grunnnámi tannlækna (50). I Finnlandi hefur verið rætt um hvort myndgreiningu á viðbeini eigi að vera hluti af læknisfræðilegri aldursgreiningu pví yfirvöld innflytjendamála grunar að einstaklingar sem sækja um alpjóðlega vernd láti fjarlægja úr sér endajaxla fyrir aldursgreiningu (50).

\section{Noregur}

Um langt skeið voru aldursgreiningar gerðar á Tannlæknadeild Háskólans í Osló og greining beinproska á einkareknu röntgenfyrirtæki sem nefnist Unilabs Norge. Tannlæknisfræðileg aldursgreining byggðist á klínískri skoðun í munni og röntgenskoðun með kjálkabreiðmynd (OPG, ortopantomogram). Pegar meta purfti aldur í kringum 18 ár var aðferð Haavikko (24) notuð á endajaxla í efri gómi. Í neðri gómi voru endajaxlar metnir eftir aðferðafræði Liversidge (2008). Rannsóknarniðurstöður Liversidge sýna aðskildar töflur fyrir drengi og stúlkur í fjórum pjóðernishópum, tveimur hópum í Bretlandi og tveimur í Suður-Afríku. Hjá peim sem vantar endajaxla var greiningin byggð á öðrum jaxli (tólf ára jaxli) samkvæmt Haavikko (24) og minnkunar rúmmáls tannkviku í framtönn samkvæmt Kvaal og fél. (25). Tveir tannlæknar sáu um aldursgreiningu og sá priðji staðfesti hana og sá um gæðaeftirlit. Vöntun endajaxla er mismunandi eftir kynpáttum (51) en reyndist 20-25\% í aldursgreiningum fylgdarlausra barna í Noregi sem segir reyndar ekkert um hvort sú vöntun var meðfædd (52).

Aldursgreining af beinproska var gerð með röntgenmyndum af vinstri hendi og úlnlið og byggðist á atlasi Greulich og Pyle (46) og framkvæmd af geislalækni hjá Unilab Norege. Samkvæmt Greulich og Pyle er vaxtarbreytingum í hönd og úlnlið lokið hjá stúlkum 18 ára og hjá strákum á aldrinum 19 ára (13).

Alda óánægju var um framkvæmd aldursgreininga í Noregi, sérstaklega hvernig niðurstöður voru túlkaðar og 
skorti á uppgefnum staðalfrávikum og öryggisbilum. Petta varð til pess að aldursgreiningar voru fluttar frá pessum tveimur stofnunum sem séð höfðu um pær um árabil til Réttarmeinadeildar Háskólans í Osló. Sett var á laggirnar nefnd sem finna ætti með hvaða hætti best væri staðið að pessum greiningum. Niðurstaðan var verkefnið BioAlder (13) sem fyrr byggist á tannproska og beinproska af hönd og úlnlið. Fullyrt var að aðferðin byggðist á stærsta rannsóknarpýði sem pá var pekkt, auk pess sem niðurstöður greiningar væru settar fram með aldursbili og öryggismörkum.

Höfundar telja að aldursgreiningar samkvæmt BioAlder séu nákvæmar en pær byggja á greiningu röntgenmyndar af hönd og úlnlið samkvæmt Greulich og Pyle (46) og aðferð Demirjian (20) á greiningu endajaxla af röntgenbreiðmynd sem grundvallast á samtekt rannsókna sem náou til 17.151 einstaklinga frá ýmsum heimshornum. Peir telja að með pví að tengja saman pessar aðferðir megi minnka skekkjumörk. peir hafa prófað kerfið á 254 Líbönum og segja að útkoman sé góð, pótt nokkrir útlagar (outliers) hafi komið fram (13).

Engin klínísk skoðun á munnholi er gerð og aðeins ein viðmiðunarrannsókn notuð við aldursgreiningu á tönnum. Er petta betri aðferðafræði en áður var gerð á tannlæknadeildinni? Höfundar pessarar greinar telja að svo sé alls ekki. Framsetning niðurstöðu aldursgreiningar er hins vegar mun betri með staðalfrávikum og öryggisbilum eins og flestar aðrar pjóðir gera.

Svípjóð

pegar bylgja einstaklinga sem sækja um alpjóðlega vernd kom á árunum 2014-2015 var ekkert opinbert kerfi til að framkvæma réttarlæknisfræðilegar aldursgreiningar. Aldursgreiningar höfðu verið gerðar hjá einkaaðilum. Stjórnvöld fólu réttarmeinadeild, Rättsmedicinalverket (RMV) að búa til slíkt kerfi. Aðferðirnar sem RMV valdi var að nota tvo aldursvísa: segulómun á neðri (distal) hluta lærleggs (MRI hné) og röntgenmyndatöku af endajöxlum neðri góms (53). MRI af hné er greint óháð af tveimur sérfræðingum í myndgreiningu (e. radiologists), röntgenmynd af jöxlum eru greindar óháð af tveimur tannlæknum.

Aldurgreining af tönnum er gerð pannig að tekin er röntgenbreiðmynd (OPG). Tveir tannlæknar greina proska endajaxla neðri góms. Endajaxlar eru taldir hafa lokið proskaferli sínum ef að minnsta kosti annar peirra hafi nád lokaproskastigi með lokuðum rótarendum, stig $\mathrm{H}$ eins og skilgreint er af Demirjian (20). Tannlæknar greina aðeins hvort lokastigi tannproskans er náð eða ekki. Önnur stig proska eru nefnd "ófullproska“.

pessir tveir tannlæknar greina hverja mynd fyrir sig án pess að hafa aðgang að mati hins. Matið er „blindað“ sem pýðir að peir hafa einungis aðgang að röntgenmyndinni og engar upplýsingar um pann sem myndin er af. Sama gildir með aldursgreiningu af hné. Til að hné sé talið hafa lokið proska purfa báðir geislafræðingarnir að vera sammála, ef ekki telst proska pess ólokið. Niðurstöður pessara greininga eru sameinaðar á pann hátt að ef annað hvort tennur eða hné er metið fullproskað er karlkyns umsækjandi metinn 18 ára eða eldri (53)(34). Árið 2018 breytti RMV reglum sínum pví íljósi kom að nýjar rannsóknir sýndu að proskaferli hnjáa lýkur hjá flestum stúlkum 16 og 17 ára $(54,55)$.

proski tanna er metinn út frá stigum Demirjian, par sem proskastig getur verið í einu af átta stigum A-H. Her lokastigið og tennur nefndar „fullproskaðar" ef að minnsta kosti annar neðri endajaxla er á pví stigi. Hné er metið „fullproskað“ ef pað hefur náð 4. eða 5. stigi samkvæmt flokkun Schmeling (54). Mismunandi proskastig tanna og hnjáa eru ekki notuð við aldursgreiningu RMV. Til dæmis, ef hné er fullproska, pá skiptir ekki máli hvort proskastig tannar sem lengst er komin í proskaferli, er í stigi G (eitt stig frá fullum proska) eða stigi $\mathrm{F}$ (tvö stig frá fullum proska), aldursgreiningin er sú sama.

peir sem gagnrýnt hafa aðferðir Svía við aldursgreiningar hafa fyrst og fremst beint spjótum sínum að greiningu beinproska af hné enda liggja mun fleiri rannsóknir af notkun handar og úlnliðs við greiningu beinproska, auk pess er aðferðin ekki almennt notuð annars staðar til aldursgreiningar. Meðal peirra sem hafa dregið aðferð Svía i efa eru Mostad og Tamsen (56). Peir yfirfóru pýði RMV 2017, par sem greindir voru 9.617 drengir og 337 stúlkur. Með eigin rannsóknum telja peir, ólíkt RMV, að fullum beinproska af hné sé að meðaltali náð á undan fullnaðar proska endajaxla í neðri gómi. Samkvæmt niðurstöðum peirra voru í pessu stóra pýði 15\% börn. Af pessum börnum voru 33\% í hættu á að vera flokkuð fullorðin. Samsvarandi hætta á að fullorðnir væru flokkaðir sem börn var nálægt 7\%.

\section{Danmörk}

Réttarfarslegar aldursgreiningar lifandi einstaklinga í Danmörku eru gerðar til pess að greina sennilegan raunaldur, ásamt vikmörkum, pegar uppgefinn aldur er dreginn í efa. Réttarmeinadeild Háskólans í Kaupmannahöfn sér um allar aldursgreiningar í Danmörku. Flestar greiningar eru gerðar á fylgdarlausum börnum, en nokkur mál varða refsiverða ábyrgð og fórnarlömb mansals. Réttarfarslegum aldursgreiningum hefur fjölgað verulega á undanförnum árum (57).

Aldursgreiningar eru almennt gerðar í samræmi við ráðleggingar Rannsóknarhóps um réttarlæknisfræðilegar 
aldursgreiningar (AGFAD) (40), nema að ekki er að öllu jöfnu tekin röntgenmynd af viðbeini, til að spara notkun röntgengeisla og ekki er framkvæmd klínísk tanna- og munnholsskoðun. AGFAD mælir með eftirfarandi aðferðafræði: 1. líkamlegri skoðun 2. greining beinproska með töku röntgenmyndar á á vinstri hönd og úlnlið og ef parf rannsókn á viðbeini og 3. tannproska með röntgenrannsókn á tönnum og kjálkum (58). I flestum löndum markar 18 ára aldur mun á barni og fullorðnum.

Líkamleg skoðun er gerðá Réttarmeinadeild Háskólans í Kaupmannahöfn af réttarmeinafræðingi. Við líkamsskoðun er hæð og pyngd mæld og áætlaður kynproski sjónrænt samkvæmt Tanner (58-60), p.e. proski brjósta, getnaðarlims, pungs og skapahára og sjúkrasaga skráð. Einnig er skrád næringarástand í uppvexti. Augljós merki um vannæringu t.d. frávik frá eðlilegri lögun beina eru metin (58).

Beinproski er metinn af röntgenlækni með röntgenmyndatöku af hönd og úlnlið á Ríkispítalanum, háskólasjúkrahúsinu í Kaupmannahöfn. Proskinn er borinn saman við atlas Greulich og Pyle (46). pegar proskaferlinu er lokið eru karlar 19 ára eða eldri og samsvarandi aldur hjá konum 18 ára og eldri (58).

Til að meta tannproska er tekin röntgenbreiðmynd (OPG) og fjórar smámyndir (periapical) af endajöxlum. Ástand tanna og tannproski er metinn og borinn saman við vísindarannsóknir sem stuðst er við. Við matið er stuðst við allar tennur p.a.m. endajaxla. proskastig endajaxla eru skilgreind samkvæmt Gleiser og Hunt (61) með síðari breytingum Köhler og fél. (62) eitt tíu stiga, 1-10 (Cr1/2-Ac). proskastigið er borið saman við aldurstöflur Köhler og fél., Haavikko (24) og Mincer og fél. (21). Pessar rannsóknir gefa upp miðgildi aldurs og staðalfrávik (SD) fyrir hvern einn endajaxl og í sumum tilfellum aðskildar tölur fyrir einstakar rætur neðrigóms endajaxla. Líklegasti aldur út frá tönnum er fengin með pví að bera saman miðgildi aldurs pegar miðað er við rætur til viðmiðunar á hinum fjórum endajöxlum. Hver tala gildir jafnt. Að lokum er aldursbilið \pm 2 ár sett sem öryggismörk. Pegar allir endajaxlar eru fullmyndaðir, stig Ac (apex closed) er aldursgreiningin 19 ára eða eldri (58).

Á réttarmeinadeildinni er nú notað forrit, "Tand aldersvurdering udregning", sem er reiknilíkan próað og vistað í rannsóknar- og upplýsingamiðstöð Háskólans í Kaupmannahöfn (RIS - IT). Forritið er grundvallað á sömu aðferðafræði sem hér hefur verið lýst og reiknar út aldur miðað við tannproska endajaxla. Aldur er gefinn upp með staðalfrávikum (SD). Í texta niðurstöðu greiningar er getið hvaða tennur hún byggist á og sennilegastan aldur. Getið er um líffræðilegan breytileika og óvissu um +/- 2 ár sem svarar til u.p.b. +/- 2 staðalfrávika (58).

Kölkun í miðlægu brjóski viðbeins er hægt að skoða með venjulegri röntgenmynd eða með sneiðmynd (CT) $(63,64)$ og lokastig næst pegar einstaklingur er eldri en tvítugur. pví er aldursgreining á viðbeini mikilvægur aldursvísir til að segja til um hvort hann sé eldri en 18 ára. Geislaskammtur getur skipt máli vegna nálægðar við mikilvæg líffæri eins og skjaldkirtil. pessi aðferð er pví ekki notuð að jafnaði í Danmörku. Í rannsókn látinna er aðferðinni beitt. Rannsóknir eru í gangi um hvort unnt sé að beita segulómun og eru sérfræðingar á réttarmeinadeildinni í Kaupmannahöfn meðal peirra $(65,66)$. Pótt Danir styðjist ekki við aldursgreiningu af viðbeini getur greiningin verið mjög mikilvæg.

Ísland

Áratugareynsla er fyrir aldursgreiningum á Íslandi. Fyrst voru pær gerðar fyrir lögreglu að ósk Embættis ríkislögreglustjóra, síðan komu fleiri að pessu verkefni, fyrst og fremst réttartannlæknar Tannlæknadeildar Háskóla Íslands (THÍ). Smám saman tók Útlendingastofnun (UTL) yfir pennan málaflokk. Engin sérstakur samningur var milli aðila, UTL hafði samband við sérfræðinga THÍ, tími var ákveðinn og fór greiningin fram á THÍ. Framan af voru aðeins fá tilfelli á ári en peim fjölgaði verulega í kjölfar mikils fjölda flóttamanna til Evrópu, Norðurlanda og Íslands árið 2015 og 2016. Fyrst og fremst var um að ræða fylgdarlaus börn, en einnig nokkur mansalsmál.

Lög um vernd og aldursgreiningu vegalausra barna er að finna í alpjóðlegum skuldbindingum sem Ísland hefur undirgengist. Par er fyrst og fremst um að ræða Barnasáttmála Sameinuðu pjóðanna (67) og samningur um réttarstöðu flóttamanna (Flóttamannasamning Sameinuðu pjóðanna) (68). Einnig skal bent á lög um útlendinga, nr. 80/2016 og einnig reglugerð um útlendinga nr. 540/2017. Fyrir liggja drög að frumvarpi til nýrra laga um útlendinga (69). Lög pessi beinast að pví að tryggja börnum rétt pann sem peim eru tryggð samkvæmt ofangreindum lögum og tryggja að fullorðnir taki sér ekki pann rétt sem er frátekinn börnum. Framkvæmdin skal gerð eins mannúðlega og unnt er og öll vafaatriði skulu metin umsækjanda um vernd í hag.

Í mars 2019 var undirritaður samningur milli Háskóla Íslands og UTL um aldursgreiningar til eins árs (70). Sá samningur var ekki endurnýjaður á grundvelli pess að ekki hafi verið staðið við ákvæði samnings að mati háskólaráðs, að ekki hafi verið leitað allra leiða áður en kæmi til aldursgreining af tönnum m.a kröfu um sálfræðiviðtöl, enda pótt fyrir liggi að pau pjóni engu vísindalegu gildi og engin rannsóknargögn styðja beitingu, gagnsemi eða áreiðanleika sálfræðilegra 
proskaprófa til aldursgreininga (7).

Aldursgreiningar voru gerðar á Tannlæknadeild HÍ. Viðstaddir aldursgreiningar voru talsmenn Útlendingastofnunar, barnaverndar, Rauða krossins, auk túlks. Greining var ekki gerð nema að fyrir lægi skriflegt sampykki einstaklings sem sækir um alpjóðlega vernd. Útlendingastofnun óskaði eftir aldursgreiningu hjá sérfræðingum Tannlæknadeildar. Niðurstaða greiningar var aðgangslæst og send UTL rafrænt á öruggan hátt. Hvað UTL gerði með niðurstöðuna er greinendum ókunn og óviðkomandi. pað er í höndum UTL hvort einstaklingnum sé veitt vernd hér á landi og niðurstöðuna er hægt að áfría til Kærunefndar útlendingamála.

Tveir réttartannlæknar sjá um skoðun á tönnum og munnholi, skrá sjúkrasögu og aðrar upplýsingar sem taldar eru skipta máli.

Tekin var stafræn röntgenbreiðmynd (OPG) og sérmyndir af jöxlum og framtönnum til að hægt sé að meta proskastig tanna. Niðurstöður voru greindar samkvæmt aðferðafræði Liversidge (2008), Mincer og fél. (21), Kullman og fél. (32) og AlQahtani og fél. (23). Í undatekningartilvikum var aldur greindur með stafrænni röntgenmynd af hönd og úlnlið samkvæmt aðferðafræði Greulich og Pyle (46). Nýlega var ákveðið að pessi aðferð við greiningu aldurs af beinproska verði framvegis notuð sem staðalaðferð við aldursgreiningar hér á landi ásamt greiningum af tönnum.

Mynd 4. Flokkun Kullman á mismunandi stigum rótarmyndunar. Figure 4. Stages of Kullman's classification of root formation.

Á Mynd 4 og Töflu 1 má sjá að pegar rót er fullmynduð fæst stigið Ac eða 7. pá er aldur viðkomandi a.m.k. 20 ára.

Tafla 1. Meðalaldur og staðalfrávik sem hvert stig rótarmyndunar gefur í

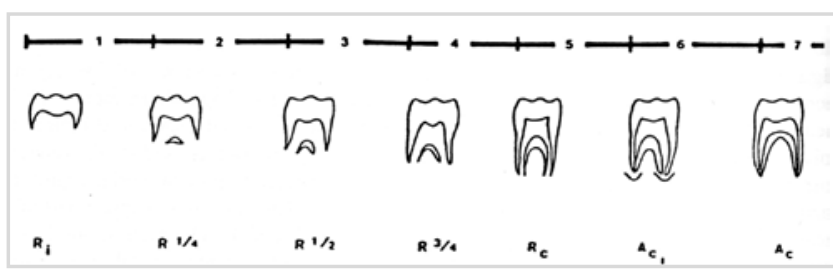

aðferð Kullman (32).

Table 1. Mean age and standard deviation for each stage according to Kullman (32).

\begin{tabular}{|c|c|c|c|c|}
\hline \multirow{2}{*}{ Stig } & \multicolumn{2}{|c|}{ Karlar } & \multicolumn{2}{c|}{ Konur } \\
\cline { 2 - 5 } & $\begin{array}{c}\text { Miðgildi } \\
\text { aldurs }\end{array}$ & sd & $\begin{array}{c}\text { Miðgildi } \\
\text { aldurs }\end{array}$ & sd \\
\hline 1 & 15.0 & 1.3 & 15.4 & 0.9 \\
\hline 2 & 15.9 & 1.0 & 16.6 & 1.7 \\
\hline 3 & 16.9 & 1.1 & 16.8 & 1.6 \\
\hline 4 & 17.3 & 1.2 & 17.9 & 1.6 \\
\hline 5 & 18.0 & 1.2 & 18.6 & 1.8 \\
\hline 6 & 19.2 & 1.0 & 19.9 & 1.6 \\
\hline
\end{tabular}

Mynd 5. Proskastig jaxla samkvæmt Liversidge (2008).

Figure 5. Molar developmental stages according to Liversidge (2008).

Greind voru proskastig tanna, oftast endajaxla, samkvæmt

\begin{tabular}{|c|c|c|c|}
\hline & $\begin{array}{c}\text { ce } \\
\text { intal cusp } \\
\text { formetion }\end{array}$ & & \\
\hline & $\begin{array}{l}\text { Coo: } \\
\text { Coalescence } \\
\text { of cusps }\end{array}$ & & $\begin{array}{c}\text { R 1/4: } \\
\text { rootiength } \\
\text { less than } \\
\text { crown lergth } \\
\text { with visible } \\
\text { bifurcatoo area }\end{array}$ \\
\hline$\infty$ & $\begin{array}{c}\text { Coc: } \\
\text { Cusp outline } \\
\text { conslete }\end{array}$ & & $\begin{array}{l}\text { R 1/2: } \\
\text { rook length } \\
\text { equals } \\
\text { crown length }\end{array}$ \\
\hline$\cong$ & $\begin{array}{c}c r 1 / 2 \\
\text { cromm hout } \\
\text { completed with } \\
\text { dentihe formation }\end{array}$ & & $\begin{array}{l}\text { R } 3 / 4 \text { : } \\
\text { three quarters } \\
\text { of root lenteth } \\
\text { developod with } \\
\text { diverge ends }\end{array}$ \\
\hline & 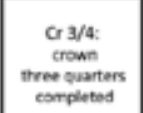 & & $\begin{array}{c}\text { RC: } \\
\text { roet length } \\
\text { completed with } \\
\text { parallel ends }\end{array}$ \\
\hline & $\begin{array}{c}\text { Cre: } \\
\text { crom congleved } \\
\text { with defned } \\
\text { sulp roof }\end{array}$ & & $\begin{array}{c}\text { A } 1 / 2 \text { : } \\
\text { operclosed } \\
\text { (hoot ends } \\
\text { converge) wath } \\
\text { wise PDL }\end{array}$ \\
\hline & $\begin{array}{c}\text { Re } \\
\text { initial root } \\
\text { formation wath } \\
\text { diverge edges }\end{array}$ & & $\begin{array}{c}\text { AC: } \\
\text { aperciosed } \\
\text { with normal } \\
\text { POC witth }\end{array}$ \\
\hline
\end{tabular}

ofangreindum fjórum aðferðum og pau borin saman við aldurstöflur sem gefa upp miðgildi aldurs og staðalfrávik. Í niðurstöðu greiningar var vísað í pessar aðferðir og aldur og staðalfrávik gefin.

Hér er dæmi um hvernig niðurstaða greiningar er í pví tilfelli að endajaxlar hafa lokið proskaferli sýnu og einstaklingur sem sækir um alpjóðlega vernd hefur gefið upp að aldur sinn sé 16 ár og 1 mánuður. Vísað er í myndir og töflur að framan.

„Samkvæmt aðferð Kullman er proskastigið 7, Ac, 


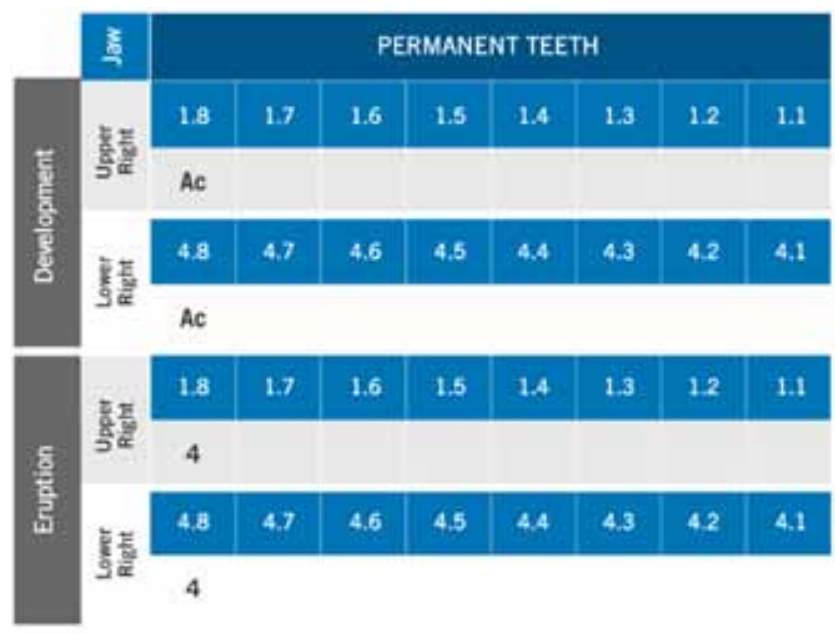

Mynd 6. Tannproska lokið (Ac), endajaxlar í bitsnertingu stig 4.

Figure 6. Third molars fully developed Ac and in occlusion (stage 4).

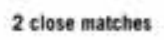

22.5 Vears 23.5 Years

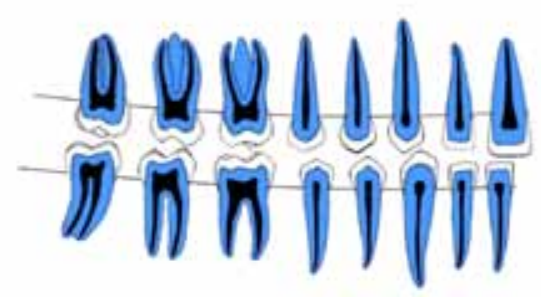

Mynd 7. Aldur samkvæmt QMUL-Atlas 22.5 - 23.5 ár

Figure 7. Age estimation according to QMUL-Atlas 22.5 - 23.5 years.

rótarendi lokaður og aldur pví amk. 19.2 ár, staðalfrávik 1.0 ár. Samkvæmt aðferð Liversidge er proskastigið Ac og aldurinn amk. 19.31 ár, staðalfrávik 1.0 ár. Samkvæmt aðferð Mincer eru proskastig allra endajaxla $\mathrm{H}$ og aldurinn samkvæmt proskastigi efri endajaxla a.m.k. 20.2 ár og staðalfrávik 2.09 ár, en neðri endajaxla a.m.k. 20.5 ár og staðalfrávik 1.97 ár. Á myndum 6 og 7 eru niðurstöður greiningar samkvæmt QMUL-Atlas AIQahtani (23), sem byggir á tannproska og framkomu tanna í munni. Samkvæmt honum getur aldurinn legið á milli 22.5 og 23.5 ár."

„Ekkert kom fram í almennri sjúkrasögu sem gæti leitt til seinkunar á tannproska. Niðurstaðan af aldursgreiningu einstaklingsins er byggð á sameiginlegu mati á sjúkrasögu, klínískri skoðun, og aldursútreikningum og mati á röntgenmyndum. Einstaklingurinn sagðist vera 16 ára og 1 mánaða. Athygli er vakin á pví að öllum proskaviðmiðum er lokið og pau breytast ekki síðar á ævinni."

„Pað er mat okkar að NN sé eldri en 18 ára“.
Gagnrýni á aldursgreiningar hér á landi

Nokkur óánægja hefur verið vegna notkunar á læknisfræðilegri aldursgreiningu hér á landi, sérstaklega af fulltrúum Rauða kross Íslands og Íslandsdeildar Barnahjálpar Sameinuðu pjóðanna. Sú óánægja virðist ekki endurspegla stefnu móðurfélaga peirra erlendis. Einnig hafa nokkrir starfsmann Háskóla Íslands með akademískar stöður, doktorsnemar og fulltrúar stúdenta lagst gegn pví að Hí framkvæmi aldursgreiningar enda pó аð pað starf tryggi fylgdarlausum börnum rétt sinn samkvæmt alpjóðlegum skuldbindingum Íslendinga og jafnframt að komi í veg fyrir að fullorðnir taki sér pann rétt sem ætlaður er börnum. Gera verður ríkar kröfur að akademísk rök séu færð fyrir málflutningi, vísað sé til virtra ritrýndra vísindagreina og alpjóðasamninga að sið fræðimanna pegar lagðar eru fram mótrök fyrir pessum vinnuaðferðum.

\section{Niðurstaða}

Nánast öll ríki í Evrópu reyna að ákveða aldur af skilríkjum. Í peim tilvikum sem pau eru ekki talin ábyggileg er leitað til sérfræðinga til framkvæma réttarlæknisfræðilega (medico-legal) aldursgreiningu. Engir sameiginlegir staðlar, ábendingar eða fyrirmæli um aðferðir við réttarfarslegar aldursgreiningu eru á heimsvísu (42) eða innan Evrópu og Evrópusambandsins $(2,3,34)$. Aðeins tvö ríki sambandsins byggja aldursgreiningu á viðtölum án pess að nota einhvers konar réttarlæknisfræðilega greiningu (3). Einstök ríki ráða hvað aðferðum er beitt og eru pær sniðnar að lagaumhverfi hvers lands. Leita parf til annarra álitsgjafa hér á landi en hingað til hafa haft sig mest í frammi, ef tryggja á sem best réttindi fylgdarlausra barna og koma í veg fyrir að fullorðnir taki sér pann rétt, en pað er markmið peirra sem sjá um aldursgreiningar hér á landi sem annars staðar.

\section{Heimildir}

1. Birth registration. Without legal proof of identity, children are left uncounted and invisible. Unicef, for every child. https://www.unicef.org/protection/birth-registration.

2. Position Paper on Age Assessment in the Context of Separated Children in Europe. Separated Children in Europe Programme (SCEP). 2012.

3. EASO Practical Guide on age assessment, second ed. EASO, European Asylum Support Office 2018. 
4. Every Child's Birth Right: Inequities and trends in birth registration. United Nations Children's Fund,. UNICEF New York, 2013.

5. Birth Registration from the start. United Nations Children's Fund. Innocenti Digest $2002 ; 9$, UNICEF Innocenti Centre, Florence..

6. Macha M, Lamba B, Avula JSS, Muthineni S, Margana P, Chitoori P. Estimation of Correlation between Chronological Age, Skeletal Age and Dental Age in Children- A Cross-sectional Study. Journal of clinical and diagnostic research : JCDR. 2017;11(9):ZC01-ZC4.

7. Ding KY MA, Straumann GH, Vist GE.. Age estimation in adolescents and young adults by psychological assessment of maturity. Norwegian Institute of Public Health.

8. Mays S. The archaeology of human bones. Routledge. Redrawn from Miles (1963: figure 10). 2003:61.

9. Elamin F, Liversidge HM. Malnutrition has no effect on the timing of human tooth formation. PloS one. 2013;8(8):e72274.

10. Chaumoitre K, Lamtali S, Baali A, Saliba-Serre B, Lahmam A, Aboussad A, et al. Influence of socioeconomic status and body mass index on bone age. Horm Res Paediatr. 2010;74(2):129-35.

11. Gelbrich B, Frerking C, Weiss S, Schwerdt S, Stellzig-Eisenhauer A, Tausche E, et al. Combining wrist age and third molars in forensic age estimation: how to calculate the joint age estimate and its error rate in age diagnostics. Ann Hum Biol. 2015;42(4):389-96.

12. Schmeling A, Grundmann C, Fuhrmann A, Kaatsch HJ, Knell B, Ramsthaler F, et al. Criteria for age estimation in living individuals. International journal of legal medicine. 2008;122(6):457-60

13. Bleka O, Rolseth V, Dahlberg PS, Saade A, Saade M, Bachs L. BioAlder: a tool for assessing chronological age based on two radiological methods. International journal of legal medicine. 2019;133(4):1177-89.

14. Garn SM, Lewis AB, Vicinus JH. Third Molar Polymorphism and Its Significance to Dental Genetics. Journal of dental research. 1963;42:SUPPL1344-63.

15. Trakiniene G, Andriuskeviciute I, Salomskiene L, Vasiliauskas A, Trakinis T, Sidlauskas A. Genetic and environmental influences on third molar root mineralization. Archives of oral biology. 2019;98:220-5.

16. Dick HM, Simpson WJ. Dental changes in osteopetrosis. Oral surgery, oral medicine, and oral pathology. 1972;34(3):408-16.

17. Lexner MO, Bardow A, Hertz JM, Nielsen LA, Kreiborg S. Anomalies of tooth formation in hypohidrotic ectodermal dysplasia. Int J Paediatr Dent. 2007;17(1):10-8.

18. Luo E, Liu H, Zhao Q, Shi B, Chen Q. Dental-craniofacial manifestation and treatment of rare diseases. Int J Oral Sci. 2019;11(1):9.

19. Ruyssinck L, Toulouse K, Bordon Cueto de Braem V, Cauwels R, Dhooge C. Impact of Hematopoietic Stem Cell Transplantation on Dental Development. Biol Blood Marrow Transplant. 2019;25(1):107-13.

20. Demirjian A, Goldstein H. New systems for dental maturity based on seven and four teeth. Ann Hum Biol. 1976;3(5):411-21.

21. Mincer HH, Harris EF, Berryman HE. The A.B.F.O. study of third molar development and its use as an estimator of chronological age. J Forensic Sci. 1993;38(2):379-90.

22. Orhan K, Ozer L, Orhan Al, Dogan S, Paksoy CS. Radiographic evaluation of third molar development in relation to chronological age among Turkish children and youth. Forensic science international. 2007;165(1):46-51.

23. AlQahtani SJ, Hector MP, Liversidge HM. Brief communication: The London atlas of human tooth development and eruption. American journal of physical anthropology. 2010;142(3):481-90.

24. Haavikko K. The formation and the alveolar and clinical eruption of the permanent teeth. An orthopantomographic study. Suom Hammaslaak Toim. 1970;66(3):103-70.

25. Kvaal SI, Kolltveit KM, Thomsen IO, Solheim T. Age estimation of adults from dental radiographs. Forensic science international. 1995;74(3):175-85.

26. Vidisdottir SR, Richter $\mathrm{S}$. Age estimation by dental developmental stages in children and adolescents in Iceland. Forensic science international. 2015;257:518 e1-7.

27. Javadinejad S, Sekhavati H, Ghafari R. A Comparison of the Accuracy of Four Age Estimation Methods Based on Panoramic Radiography of Developing Teeth. J Dent Res Dent Clin Dent Prospects. 2015;9(2):72-8.

28. Cameriere R, De Angelis D, Ferrante L, Scarpino F, Cingolani M. Age estimation in children by measurement of open apices in teeth: a European formula. International journal of legal medicine. 2007;121(6):449-53.

29. Willems $G$, Van Olmen A, Spiessens B, Carels C. Dental age estimation in Belgian children: Demirjian's technique revisited. J Forensic Sci. 2001;46(4):893-5.

30. Galic I, Vodanovic M, Cameriere R, Nakas E, Galic E, Selimovic E, et al. Accuracy of Cameriere, Haavikko, and Willems radiographic methods on age estimation on
Bosnian-Herzegovian children age groups 6-13. International journal of legal medicine. 2011;125(2):315-21.

31. Liversidge HM, Marsden PH. Estimating age and the likelihood of having attained 18 years of age using mandibular third molars. British dental journal. 2010;209(8):E13.

32. Kullman $L$, Johanson $G$, Akesson $L$. Root development of the lower third molar and its relation to chronological age. Swed Dent J. 1992;16(4):161-7.

33. Thevissen PW, Alqerban A, Asaumi J, Kahveci F, Kaur J, Kim YK, et al. Human dental age estimation using third molar developmental stages: Accuracy of age predictions not using country specific information. Forensic science international. 2010;201(13):106-11.

34. Thevissen PW, Kvaal SI, Willems G. Ethics in age estimation of unaccompanied minors. J Forensic Odontostomatol. 2012;30 Suppl 1:84-102.

35. Sisman Y, Uysal T, Yagmur F, Ramoglu SI. Third-molar development in relation to chronologic age in Turkish children and young adults. Angle Orthod. 2007;77(6):10405 .

36. Schmeling A, Geserick G, Reisinger W, Olze A. Age estimation. Forensic science international. 2007;165(2-3):178-81.

37. Thevissen PW, Fieuws $S$, Willems $G$. Human dental age estimation using third molar developmental stages: does a Bayesian approach outperform regression models to discriminate between juveniles and adults? International journal of legal medicine. 2009.

38. Gunst K, Mesotten K, Carbonez A, Willems G. Third molar root development in relation to chronological age: a large sample sized retrospective study. Forensic science international. 2003;136(1-3):52-7.

39. Meinl A, Tangl S, Huber C, Maurer B, Watzek G. The chronology of third molar mineralization in the Austrian population--a contribution to forensic age estimation. Forensic science international. 2007;169(2-3):161-7.

40. Schmeling A, Dettmeyer R, Rudolf E, Vieth V, Geserick G. Forensic Age Estimation. Dtsch Arztebl Int. 2016;113(4):44-50.

41. Thevissen $P$, Kvaal $S$, Willems $G$. Ethics in age estimation of unaccompanied minors. J Forensic Odontostomatol 2012;30(Suppl 1):84-103.

42. Pradella F, Pinchi V, Focardi M, Grifoni R, Palandri M, Norelli GA. The age estimation practice related to illegal unaccompanied minors immigration in Italy. J Forensic Odontostomatol. 2017;35(2):141-8.

43. Nystrom ME, Ranta HM, Peltola JS, Kataja JM. Timing of developmental stages in permanent mandibular teeth of Finns from birth to age 25. Acta odontologica Scandinavica. 2007;65(1):36-43.

44. Kataja M, Nystrom M, Aine L. Dental maturity standards in southern Finland. Proc Finn Dent Soc. 1989;85(3):187-97.

45. Chaillet N, Nystrom M, Demirjian A. Comparison of dental maturity in children of different ethnic origins: international maturity curves for clinicians. J Forensic Sci. 2005;50(5):1164-74.

46. Greulich WW, Pyle SI. Radiographic atlas of skeletal development of the hand and wrist. Second edn Stanford University Press, Stanford, California. 1959.

47. Lindsey RC, Mohan S. Skeletal effects of growth hormone and insulin-like growth factor-l therapy. Mol Cell Endocrinol. 2016:432:44-55.

48. Carson JA, Manolagas SC. Effects of sex steroids on bones and muscles: Similarities, parallels, and putative interactions in health and disease. Bone. 2015;80:67-78.

49. Christmas C, O'Connor KG, Harman SM, Tobin JD, Munzer T, Bellantoni MF, et al. Growth hormone and sex steroid effects on bone metabolism and bone mineral density in healthy aged women and men. J Gerontol A Biol Sci Med Sci. 2002;57(1):M12-8.

50. Metsaniitty M, Varkkola O, Waltimo-Siren J, Ranta H. Forensic age assessment of asylum seekers in Finland. International journal of legal medicine. 2017;131(1):24350.

51. Singh A, Peres MA, Watt RG. The Relationship between Income and Oral Health: A Critical Review. Journal of dental research. 2019;98(8):853-60.

52. Haugen M EL, Tvete IF, Kvaal SI. Development of improved methods or basis for medical age assessments of minors and young adults. Norwegian Computing Center 2016.

53. Rättsmedicinalverkets. Metodbeskrivning för Rättsmedicinalverkets medicinska åldersbedömningar. 18- årsgränsen. Dnr D17-90200. 2017.

54. Ottow C, Schulz R, Pfeiffer H, Heindel W, Schmeling A, Vieth V. Forensic age estimation by magnetic resonance imaging of the knee: the definite relevance in bony fusion of the distal femoral- and the proximal tibial epiphyses using closest-to-bone T1 TSE sequence. Eur Radiol. 2017;27(12):5041-8.

55. Tamsen F. En majoritet av flickor nära 18 år kan felbedömas som vuxna med MR-knä 
Läkartidningen. 2017;114:EWFM.

56. Mostad $P$, Tamsen F. Error rates for unvalidated medical age assessment procedures. International journal of legal medicine. 2019;133(2):613-23.

57. Niels Dyrgaard Jensen foDoFP, University of Copenhagen. Skriflegar upplýsingar. 02/12/2016

58. Larsen ST, Arge S, Lynnerup N. The Danish approach to forensic age estimation in the living: how, how many and what's new? A review of cases performed in 2012. Ann Hum Biol. 2015;42(4):342-7.

59. Marshall WA, Tanner JM. Variations in the pattern of pubertal changes in boys. Archives of disease in childhood. 1970;45(239):13-23.

60. Marshall WA, Tanner JM. Variations in pattern of pubertal changes in girls. Archives of disease in childhood. 1969;44(235):291-303.

61. Gleiser I, Hunt EE, Jr. The permanent mandibular first molar: its calcification, eruption and decay. American journal of physical anthropology. 1955;13(2):253-83.

62. Köhler S, Schmelzle R, Loitz C, Püschel K. Development of wisdom teeth as a criterion of age determination. Annals of anatomy - Anatomischer Anzeiger 1994;176(4):339-45.

63. Schmeling A, Schulz R, Reisinger W, Muhler M, Wernecke KD, Geserick G. Studies on the time frame for ossification of the medial clavicular epiphyseal cartilage in conventional radiography. International journal of legal medicine. 2004;118(1):5-8.

64. Kellinghaus M, Schulz R, Vieth V, Schmidt S, Schmeling A. Forensic age estimation in living subjects based on the ossification status of the medial clavicular epiphysis as revealed by thin-slice multidetector computed tomography. International journal of legal medicine. 2010;124(2):149-54.

65. Schmidt S, Ottow C, Pfeiffer H, Heindel W, Vieth V, Schmeling A, et al. Magnetic resonance imaging-based evaluation of ossification of the medial clavicular epiphysis in forensic age assessment. International journal of legal medicine. 2017;131(6):1665-
73

66. Tangmose S, Jensen KE, Villa C, Lynnerup N. Forensic age estimation from the clavicle using 1.0T MRI--preliminary results. Forensic science international. 2014;234:7-12.

67. Samningur Sameinuơu pjóđanna um réttindi barnsins. 192 nr. 18 2. nóvember. Laagasfn Íslensk lög 1 janúar 2005, útgáfa 131a.http://www.althingi.is/ lagas/131a/1992018.2c5.html.

68. Samningur um réttarstöđu flóttamanna. http://wwwhumanrightsis/is/mannrettindi-ogisland/helstu-samningar-og-yfirlysingar/sameinudu-thjodirnar/samningur-umrettarstodu-flottamanna. 1951

69. Drög að frumvarpi til nýrra laga um útlendinga. https://wwwstjornarradidis/media/ innanrikisraduneyti-media/media/frettir-2015/utlendingalagafrumvarp_24082015_ lokapdf.

70. Samningur Útlendingastofnunar og Háskóla İslands um klíníska munnholsskoðun og röntgenmyndatöku. https://wwwutlis/indexphp/um-utlendingastofnun/ samstarfssamningar. 2019.

\section{Útskriftarnemar frá THÍ 2020}

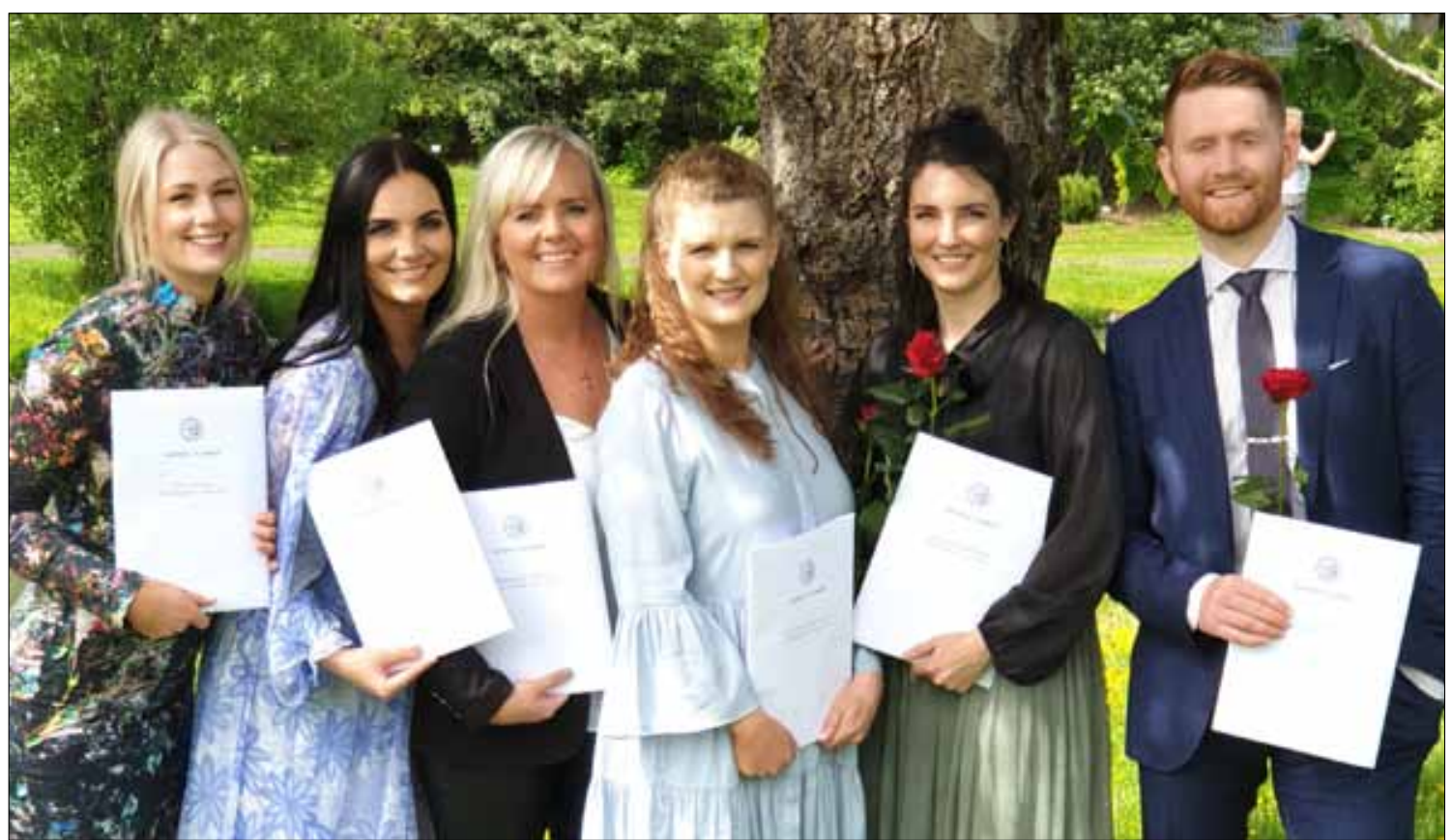

FRÁ VINSTRI: BIRTA PÓRSDÓTTIR, SVALA BJÖRK JÓNSDÓTTIR, HRAFNHILDUR ÝR ÓLAFSDÓTTIR, AUĐUR ÖSP KRISTBJÖRNSDÓTTIR, CAMILLA PETRA SIGURĐARDÓTTIR OG GUĐBJARTUR PRÁINSSON 
English Summary

Age assessment of unaccompanied minors

- why and how?

\author{
SVEND RICHTER, DDS, MSC, ASSOCIATE PROFESSOR EMERITUS \\ FACULTY OF ODONTOLOGY, UNIVERSITY OF ICELAND. \\ SIGRIDUR ROSA VIDISDOTTIR, DDS, MSC, ASSISTANT PROFESSOR \\ FACULTY OF ODONTOLOGY, UNIVERSITY OF ICELAND.
}

ICELANDIC DENTAL JOURNAL 2020; 38: 22-34

doi: 10.33112/tann.38.1.3

\begin{abstract}
Approximately one third (35 per cent) of the global population of children under five have not been rightly registered. The lowest levels of birth registration are found in sub-Saharan Africa (44\%) and in South Asia (39\%), which are the same countries that most of the unaccompanied minors seeking asylum in Europe and Iceland are from. Many of them may be unaware of their exact date of birth and travel without appropriate identity documents. With respect to rights and obligations for asylum seekers, there are significant legal differences between minors and adults. For immigration authorities it is important to determine whether an asylum seeker is older or younger than 18 years of age. Most European countries perform a forensic medical age assessment if it is not possible to assess age with reasonable certainty based on other available credible information. Only two EU Member States, age assessment procedures are carried out exclusively through interviews, without the use of any type of medical test. Most European countries use a combination of dental and bone development for age estimation. All the Nordic countries use age estimation based on dental development and all on skeletal development. Those who use skeletal age all use hand and wrist radiography, except Sweden which use MRI knee. In Denmark age estimation is also based on sexual development. There has been some disagreement about age estimation in Norway, Sweden and Iceland. Several disciplines have been incorporated in the project of making changes in Norway and Sweden: odontology, pediatrics, radiography, statistical modeling and image analysis. Those who have mostly faced how best to deal with age estimation in Iceland do not come from these specialist disciplines and are completely unrelated. An agreement was made between The Directorate of Immigration and the University of Iceland, which was not renewed, as the university believed that the Directorate of Immigration had not fulfilled the agreement.
\end{abstract}

Keywords: Age estimation, unaccompanied minors, Europe, Iceland

Correspondence: Svend Richter - svend@hi.is, Sigridur Rosa Vidisdottir - srv2@hi.is

\section{Jón Viðar Arnórsson heiðursfélagi í Tannlæknafélagi Íslands}

Jón Viðar Arnórsson var kosinn heiðurfélagi íTannlæknafélagi Íslands á aðalfundi félagsins 12. nóvember s.l. sem fór fram í gegnum fjarfund. Tannlæknablaðið óskar Jóni Viðari til hamingju enda er hann vel að heiðrinum kominn.

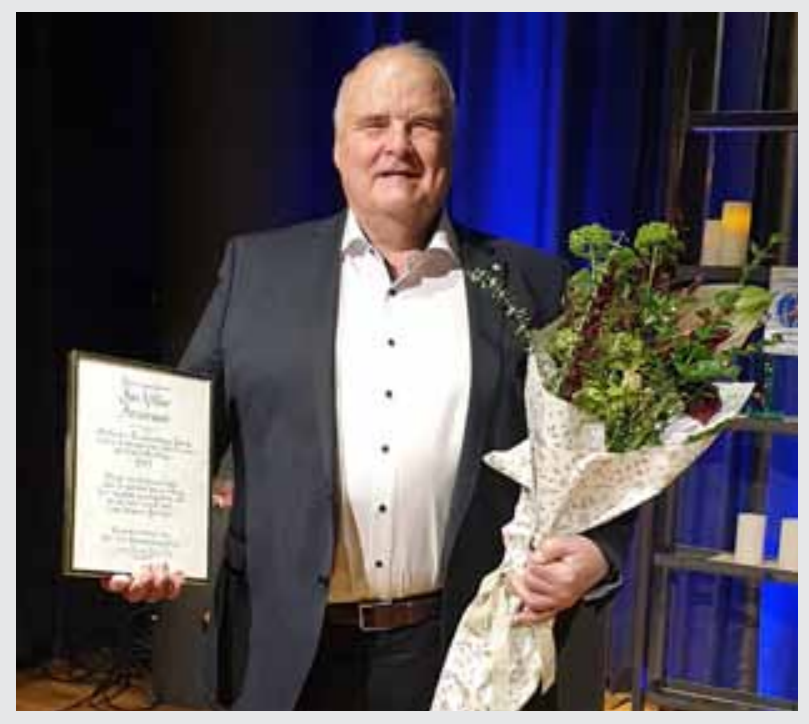

